\title{
WYBÓR BISKUPA RZYMU DO IV WIEKU
}

Już sam fakt, że podejmując zagadnienie papiestwa, za każdym razem (w mniejszym lub większym stopniu) odwołać się musimy do rzymskiej stolicy biskupiej, wskazuje na jej wyjątkowość. Tę wyjątkowość nadaje jej postać rybaka $z$ Galilei, którego Zbawiciel wybrał, nazwał Piotrem oraz postawił na czele apostołów, i który - jak to wynika $z$ formalnych świadectw historycznych, pod koniec życia był biskupem rzymskim i tam poniósł śmierć męczeńską ${ }^{1}$.

Piotr jako jedyny doświadczył cudownego, boskiego wyboru. Potem przyszedł taki moment, kiedy to jego urząd musiał odziedziczyć ktoś inny. Jak to się dokonywało w przypadku bezpośrednich następców Piotra i tych dalszych, aż do IV wieku? Oto jest zagadnienie, które stanie się tematem wiodącym niniejszego artykułu. Zostanie tu ono przedstawione w dwóch zasadniczych punktach: pierwszy z nich dotyczyć będzie sposobu powoływania bezpośrednich następców św. Piotra, w drugim natomiast ukazane zostaną zasady elekcji biskupów rzymskich od II wieku. Powyższy podział wydają się narzucać same wyniki badań analizowanego zagadnienia.

\section{PIERWSI NASTEPCY SW. PIOTRA}

Uwzględniając dane biblijne, świadectwa najstarszej tradycji chrześcijańskiej oraz powagę, jaką cieszyli się apostołowie w pierwotnym Kościele, należałoby przyjąć, że wyznaczali oni mocą swojego autorytetu pierwszych pasterzy dla tworzonych przez siebie wspólnot kościelnych ${ }^{2}$. I tak po męczeńskiej śmierci Jakuba - pierwszego biskupa Jerozolimy - apostołowie i uczniowie Pańscy, którzy zostali jeszcze przy życiu wybrali na jego miejsce Szymona syna Kleofasa ${ }^{3}$. Podobnie postępował też św. Jan apostol, kiedy to po swym powro-

${ }^{\prime}$ Por. Cz. Bartnik, Kościót Jezusa Chrystusa, Wroclaw 1982, 262 n.

${ }^{2}$ Por. W. Szcześniak, Dzieje Kościota katolickiego, t. 1. Warszawa 1902, 78.

${ }^{3}$ Por. Eusebius, HE III 11, tłum. A. Lisiecki: Historia kościelna, POK 3, Poznań 1924, reprint Warszawa 1993, 111. 
cie $z$ wygnania na Patos objeżdżał okolice Efezu, by tam ustanawiać biskupów i wybierać do grona kleru tych, „,których mu Duch oznaczył”4. Nie inaczej też chyba postąpił i św. Piotr apostoł. Organizując hierarchicznie rzymską społeczność wierzących wyznaczył on prawdopodobnie jeszcze za życia swojego następcę ${ }^{5}$ Z podobną praktyką można się spotkać jeszcze przy końcu IV wieku, gdy biskup Walerian w Hipponie, jeszcze za swego życia zatroszczy się o swojego następcę na stolicy biskupiej ${ }^{6}$.

Za faktem, że Piotr osobiście ustanowił swojego następcę, przemawia też cenne świadectwo $z$ literatury apokryficznej, jakim jest niewątpliwie list Pseudo-Klemensa Rzymskiego do Jakuba Jerozolimskiego ${ }^{7}$. Dokument ten, jako apokryf nie jest wymysłem ani fałszerstwem w dosłownym tego słowa znaczeniu, gdyż tego rodzaju pisma w tamtym czasie bliskie były realiom życia autorów ${ }^{8}$. Autor listu do biskupa Jerozolimy nie wymyślił sam z siebie tezy o legalnym ustanowieniu następcy św. Piotra i przekazaniu jemu oraz wszystkim, którzy po nim będą, Piotrowej władzy, ale do funkcjonującej wówczas tezy dostosował elementy swojego opowiadania ${ }^{9}$. I tak z listu do Jakuba Jerozolimskiego dowiadujemy się, że Piotr na krótko przed swoją śmiercią w obliczu zgromadzonych wiernych Kościoła Rzymskiego, ustanowił Klemensa ich biskupem i przekazał mu swoją władzę ${ }^{10}$.

Głównie sława Klemensa - trzeciego z kolei następcy św. Piotra - zdecydowała zapewne o tym, że autor apokryfu pominął zarówno Linusa, jak i Anakleta (dwóch bezpośrednio następujących po apostole Piotrze biskupów Rzymu), i przekazanie urzędu oraz władzy Piotrowej związał bezpośrednio $\mathrm{z}$ bardziej znanym powszechnie autorem listu do Koryntian ${ }^{11}$. Podobna tendencja uwidoczni się także w słynnej liście biskupów rzymskich, ustalonej przez św. Ireneusza, gdzie autor znacznie więcej miejsca poświęca Klemensowi ani-

${ }^{4}$ Por. tamże, III 23 (6-7).

5 Por. O. Narbutt, Kościól Rzymu w pierwszym wieku, „Więź” 12 (1977) nr $12,63$.

${ }^{6}$ Por. Possidius, Vita Sancti Augustini, tłum. P. Nehring, ŹM 26, Kraków 2002, 65.

7 Epistola Clementis ad Jacobum (PG 2, 31-56) - znajduje się ona wśród 21 homilii i dwu listów przesłanych przez Piotra i Klemensa do św. Jakuba, brata Jezusa, bpa Jerozolimy, które są wprowadzeniem do zmyślonych mów św. Piotra przeciw gnostykom i których powstanie należy datować na 1. pol. III wieku, por. B. Altaner - B. Stuiber, Patrologia, thum. P. Pachciarek, Warszawa $1990,213 n$.

${ }^{8}$ Por. W. Ulmann, Some remarks on the significance of the Epistola Clementis in the PseudoClementines, StPatr 4 (1961) 334.

9 Por. tamże.

${ }^{10}$ Por. Epistola Clementis ad Jacobum 2-3, PG 2, 35: „In ipsis autem diebus, quibus brevi moriturus erat, congregatis fratribus [...] [Simon Petrus] coram Ecclesia dixit: «Audite me, fratres et conservi; Quoniam, sicut edoctus sum ab eo, qui misit me, Domine et magistro Iesu Christo, dies mortis meae appropinquat, Clementem hunc episcopum vobis ordino; qui meam sermonem cathedram credo [...]. Haec illo dicente, ego procidens rogabam eum, cathedrae honorem et potestatem deprecans»".

11 Por. Ulmann, art. cyt., s. 333. 
żeli jego dwom poprzednikom, a nawet stosuje on inną terminologię odnośnie jego następstwa po apostołach ${ }^{12}$. To mogło $z$ kolei stanowić punkt wyjścia dla Tertuliana, który twierdził, że Klemens otrzymał święcenia $\mathrm{z}$ rąk samego Księcia apostołów ${ }^{13}$, a także dla autora apokryficznego listu do Jakuba Jerozolimskiego ${ }^{14}$. W późniejszym okresie Epifaniusz z Salaminy, usiłując jakoś pogodzić tradycyjną tezę, w myśl której bezpośrednim następcą św. Piotra był Linus, a potem Anaklet, z wypowiedzią Tertuliana, opracowal teorię, według której Klemens wprawdzie był wyświęcony przez Piotra, ale dla zachowania pokoju zrzekł się swojego urzędu na rzecz Linusa ${ }^{15}$.

Oczywiście, jest to tylko interpretacja Epifaniusza, który mając w pamięci walki i zabiegi o zasiadanie na stolicach biskupich nie mógł sobie wyobrazić normalnego następstwa, jakie mogło się na urzędzie Piotra dokonywać ${ }^{16}$. Niepokoje, jakie niekiedy towarzyszyły elekcjom biskupim w późniejszych wiekach, mogły zaciemnić to, co miało miejsce w Rzymie na samym początku przekazywania apostolskiej sukcesji. Mianowicie - tak jak kiedyś Chrystus spośród swoich uczniów wybrał dwunastu apostołów i na ich czele postawił Piotra, podobnie i Książę apostołów na czele duchowieństwa rzymskiego mógł postawić Linusa oraz dobrać sobie jeszcze Anakleta ${ }^{17}$ i Klemensa jako najbliższych współpracowników, przejmujących potem jego urząd. Ma to swoje głębokie uzasadnienie, jeśli weźmiemy pod uwagę słowa, które Klemens już jako biskup Rzymu, kieruje do Koryntian pisząc:

„nikt nie ma prawa usuwać $z$ urzędu ludzi ustanowionych na nim, czy to przez samych apostołów, czy też później przez innych czcigodnych mężów za zgodą całego Kościoła"18.

Skoro z taką oczywistością wykłada Klemens Koryntianom zasady otrzymane od apostołów co do urzędów w Kościele, to by znaczyło, że w Rzymie nie było w tym względzie problemów ${ }^{19}$. Nikt tu nie kwestionował autorytetu Piotra w kwestii wyboru współpracowników, toteż właśnie ci wybrani przez niego:

12 Por. tamże; Irenaeus, Adversus haereses III 3, 3.
13 Por. De praescriptione haereticorum 32.
14 Por. Ulmann, art. cyt., s. 334.
15 Por. Panarion 27, 6, PG $41,371$.
16 Por. Narbutt, Kościót Rzymu w pierwszym wieku, s. 64 .
17 Idąc za późniejszym świadectwem z kręgów Kościoła Syryjskiego (Konstytucje Apostolskie) należaloby przypuszczać, że był on związany z dzialalnością misyjną sw. Pawła w Rzymie. Mielibyśmy tym samym piękny przejaw szacunku św. Piotra dla misyjnego dziela św. Pawla i kręgu tych ludzi, których on osobiście zrodzit dla Chrystusa przez swoje przepowiadanie Ewangelii Rzymianom.

18 Epistola ad Corinthios 44, 3, SCh 167, 172, thum. A. Świderkówna, BOK 10, Kraków 1998,71 .

19 Por. J. Rostworowski, Charakter $i$ znaczenie biskupstwa $w$ pierwszych dwóch wiekach dziejów Kościola, Kraków 1925, 129nn. 
Anaklet i Klemens mogli pełnić kolejno jego urząd po śmierci Linusa. Za taką hipotezą przemawia fakt, że w I wieku hierarchia kościelna jest uważana za instytucję Chrystusa i opiera się bezpośrednio na powadze apostołów. Dlatego godność biskupią przekazuje się wówczas przez następstwo, zaś gmina może mieć tylko w tej sprawie głos doradczy ${ }^{20}$.

Potwierdzeniem tej właśnie procedury następstwa bezpośrednio po Piotrze na stolicy biskupiej w Rzymie, jaka wyżej została zaprezentowana, wydaje się być także najstarsza liturgiczna tradycja Kościoła rzymskiego, która znalazła swe ucieleśnienie w Kanonie Rzymskim, gdzie mamy wymienionych pierwszych trzech następców św. Piotra na biskupstwie rzymskim w kolejności: Linus, Klet $^{21}$ i Klemens ${ }^{22}$. Fakt, że imiona bezpośrednich następców św. Piotra znalazły swe miejsce w liturgii Kościoła rzymskiego, świadczy o tym, jak wielką i wspaniałą instytucją w oczach pierwszych chrześcijan był episkopat. Z tego powodu pierwsi biskupi następujący po apostołach, czy to w Rzymie, czy też w innych zakładanych przez apostołów stolicach, otaczani byli przez swoje wspólnoty niezwykłą czcią ${ }^{23}$. Znajdujemy więc $w$ tym potwierdzenie nie tylko listy kolejnych następców św. Piotra, ale także uznanie jego wielkiej powagi i autorytetu, mocą którego powołal on swych bezpośrednich następców.

Chociaż św. Piotr, podobnie zresztą jak inni apostołowie, nie dał konkretnych wytycznych dotyczących sposobu powoływania swych kolejnych następców $^{24}$, to jednak papież Klemens zastosował się w tym względzie do przykładu pierwszego biskupa Rzymu wyznaczając osobiście swojego następcę. Wskazują na to słowa Euzebiusza, który pisze, że „Klemens, biskup rzymski, urząd swój pozostawił w spuściźnie Ewarystowi i umart"25. Wraz ze śmiercią tego papieża kończy się pierwszy okres w dziejach Kościoła Rzymskiego. Ciągłość apostolskiej sukcesji, jak to wyżej zostało ukazane, kontynuował Ewaryst jeszcze $z$ ustanowienia Klemensa, następni zaś biskupi rzymscy byli już najprawdopodobniej wybierani - przez kler i lud miasta ${ }^{26}$.

${ }^{20}$ Por. J. Czuj, Hierarchia u św. Augustyna, Lublin 1925, 5.

21 Klet - jest to skrócona forma od pełnego imienia Anakletus. Uwzględnienie tego faktu przez autorów Katalogu Liberiusza [PL 13.448] i Liber Pontificalis [III i V] doprowadzilo do tego, że rozróżniają oni dwóch papieży: Kletusa i Anakletusa. W rzeczywistości chodzi o jedną osobę. Imię Anakletus wywodzi się od greckiego przymiotnika, oznaczającego tyle, co nienaganny. Określenie to było dość częstym imieniem niewolnika, co mogłoby sugerować pochodzenie społeczne tego papieża, por. J.N.D. Kelly, Encyklopedia papieży, tłum. T. Szafrański, Warszawa 1998, 18.

22 Por. Mszat Rzymski, Poznań 1986, 609-619; zob. także E. Lodi, Enchiridion euchologicum fontium liturgicorum, Roma 1979, 1746-1777 oraz M. Starowieyski, Eucharystia pierwszych chrześcijan, Kraków 1997, 214nn.

23 Por. Rostworowski, dz. cyt., s. 114.

24 Por. tamże, s. 128.

${ }^{25}$ Eusebius, HE III 34, SCh 31, 146-147, thum. A. Lisiecki: Historia kościelna, POK 3, Poznań $1924,135$.

${ }^{26}$ Por. Narbutt, art. cyt., s. 73. 


\section{ZASADY POWOŁYWANIA KANDYDATÓW NA STOLICE PIOTROWA OD II DO IV WIEKU}

Wybór duchownych, który pierwotnie w Kościele był przywilejem apostołów i uczniów apostolskich, od początku II wieku zaczyna stopniowo stawać się dziełem duchowieństwa i ludu miasta oraz sąsiednich biskupów ${ }^{27}$. Nie było to wynikiem odgórnych rozporządzeń kościelnych, ale naturalnego procesu wchodzenia chrześcijaństwa w spoleczno-prawny dorobek cywilizacji rzymskiej. Od czasów republikańskich Rzymianie nie byli tylko biernym przedmiotem w rękach swej władzy, ale mogli wyrażać swoją wolę przegłosowując decyzje dotyczące prawie wszystkich ważniejszych dziedzin życia, jak np. prawa publicznego i prywatnego, dyplomacji, wojny, pokoju, itd. Do obywateli należał też, zwłaszcza w czasach republiki, wybór urzędników państwowych ${ }^{28}$.

Oczywiście, faktem jest, że rzymski system wyborczy był uporządkowany hierarchicznie i ograniczal prawa warstw niższych. Lud nie mógł np. zwoływać się sam, ani nie miał swobody wypowiedzi. Zwykły obywatel nie wybierał kwestii, w jakiej był zapytywany. Bez względu na to, jakiego rodzaju byłoby zgromadzenie - wyborcze, ustawodawcze czy sądownicze - konkretny obywatel nie dyskutował w podejmowanych kwestiach, ale jedynie odpowiadał "tak" lub „nie” na postawione przez urzędnika pytanie. Zwykły więc obywatel pozbawiony był $w$ takim systemie wyborczym prawa do inicjatywy, stawiania pytań, dyskusji i formułowania propozycjii ${ }^{29}$.

$\mathrm{Na}$ tle rzymskich zwyczajów wyborczych, sięgających swymi korzeniami czasów królestwa, i bujnie rozwiniętych w okresie republikańskim ${ }^{30}$, staje się dla nas zrozumiały udział całej lokalnej wspólnoty wierzących w elekcji swojego biskupa. Łatwiej nam też odczytać rolę tak hierarchii kościelnej, jak i ludu przy powoływaniu nowego następcy św. Piotra.

W przypadku opróżnienia rzymskiej stolicy biskupiej postępowano tu zapewne tak, jak w podobnej sytuacji czyniono w większości lokalnych Kościołów w tym czasie. Duchowieństwo rzymskie w porozumieniu z okolicznymi biskupami zwoływało zgromadzenie, zwane synaksą ${ }^{31}$. Synaksa odbywała się w niedzielę ${ }^{32}$. Uczestniczyli w niej wszyscy wierni wraz z duchowieństwem Kościoła

27 Por. K. Bihlmeyer - H. Tüchle, Historia Kościoła, I, thum. J. Klenowski, Warszawa 1971, 116.

28 Por. C. Nicolet, Obywatel polityk, w: Cztowiek Rzymu, thum. P. Bravo, Warszawa 1997, 44nn.

${ }^{29}$ Por. tamże.

${ }^{30}$ Por. J.C. Fredouille, Slownik cywilizacji rzymskiej, tłum. M. Chołdyk - K. Jachieć, Katowice 1998,310 .

31 Synaksa - termin pochodzenia greckiego używany w pierwotnym chrześcijaństwie głównie na określenie uroczystego zgromadzenia wiernych, zgromadzenia eucharystycznego (sacra Synaxis), a nawet Komunii św. i Eucharystii, por. A.G. Hamman, Życie codzienne pierwszych chrześcijan 95-197, thum. A. Guryn - U. Sudolska, Warszawa 1990, 170.

32 Hippolytus, Traditio Apostolica 1, 2, SCh 11 bis, 40, thum. H. Paprocki: Tradycja aposiolska, STV 14 (1976) z. 1, s. 151. 
Rzymskiego oraz pobliscy biskupi ${ }^{33}$. Zgromadzenie to miało charakter liturgiczny, gdyż kończyła je Eucharystia sprawowana przez nowo wybranego biskupa $^{34}$. Wybór przebiegał w ten sposób, że najpierw ludowi proponowano imię kandydata, którym był jeden z członków gminy, zazwyczaj diakon lub $\operatorname{kapłan}^{35}$. Głosowanie miało charakter ustny ${ }^{36} \mathrm{i}$ winno było ostatecznie zakończyć się zgodą wszystkich na jednego kandydata ${ }^{37}$.

Zgoda wspólnoty kościelnej przy wyborze nowego biskupa w analizowanym przez nas okresie jest bardzo ważna. Wspólnota chrześcijańska ma bowiem w tym czasie władzę wybierania sobie biskupa albo odrzucania kandydata narzuconego siłą ${ }^{38}$. Choć wierni w poszczególnych gminach chrześcijańskich mieli stosunkowo duży wpływ na wybór swojego biskupa, to jednak nie należy zbytnio przeceniać ich roli; można raczej przypuszczać, że lud w porozumieniu $\mathrm{z}$ miejscowym klerem tylko objawiał życzenie, kogo $\mathrm{z}$ miejscowego duchowieństwa chciałby mieć biskupem. Rola ludu w elekcjach biskupich w analizowanym przez nas okresie sprowadzała się raczej do wystawienia przez swą aklamację świadectwa moralności kandydatowi ${ }^{39}-\mathrm{w}$ czym zresztą lud, jak przyznaje św. Cyprian, „najbardziej ma władzę”40. Podobna, jak się można domyślać, była też rola kleru przy elekcji nowego biskupa ${ }^{41}$. Zasadniczy zatem głos należał raczej do zebranych na elekcji biskupów ${ }^{42}$, o czym też wyraźnie pisze św. Cyprian, w jednym ze swoich listów, mówiąc, iż następca Fabiana „zostal uczyniony przez wielu naszych kolegów, którzy wtedy byli w mieście" ${ }^{43}$. Wynika z powyższego, że decydującą rolę w powoływaniu nowego biskupa mieli przede wszystkim inni biskupi: oni w Kościele zajmują miejsce jakby Boga samego, dlatego przez nich realizuje się też wola Boża w powoływaniu do stanu biskupiego 44 .

Zechciejmy jednak pójść dalej i prześledzić, co działo się później, gdy kandydat został już zgłoszony i zaopiniowany przez duchowieństwo i lud lokalnej wspólnoty wobec zebranych biskupów. Otóż w tym momencie udzielano głosu samemu kandydatowi, który miał teraz obowiązek - niejako przed trybunałem Boga Ojca i Chrystusa w obecności Ducha Świętego, wszystkich

${ }^{33}$ Por. Hamman, dz. cyt., s. 170.

34 Por. Cyprianus, Epistula 67, 5, CCL 3C, 454-455, thum. W. Szołdrski, PSP 1, Warszawa $1969,230-231$

35 Por. Traditio Apostolica 1, 3.

${ }^{36}$ Por. Hamman, dz. cyt., s. 170.

37 Por. Hippolytus, Traditio Apostolica 1,1.

38 Por. Cyprianus, Epistula 67, 3.

${ }^{39}$ Por. M. Sieniatycki, Hierarchia kościelna wedlug św. Cypriana, AK 21 (1935) t. 35, 420.

${ }^{40}$ Cyprianus, Epistula 67, 3, CCL 3C, 452, PSP 1, 229.

41 Por. tamże.

42 Por. Cyprianus, Epistula 55, 8.

${ }^{43}$ Tamże, CCL 3B, 265, PSP 1, 146.

44 Tamże. 
świętych oraz tych, którzy pełnią posługę - zaprezentować swoją osobę i potwierdzić wymagane przymioty, aby zgromadzeni na elekcji mogli się ostatecznie upewnić, że godzien on jest udzielonej mu posługi ${ }^{45}$. Po wysłuchaniu kandydata rozpoczynała się właściwa praca uczestniczących w synaksie biskupów. Ich zadaniem było najpierw rozstrzygnięcie, czy wyboru dokonano prawidłowo. Gdy to zostało uczynione, biskupi musieli sprawdzić, czy kandydat jest aprobowany przez wszystkich. Następowało więc potrójne pytanie o to, czy zgromadzony lud uważa wybranego za godnego. Jeśli odpowiedź ludu była twierdząca, wówczas przystępowano do udzielenia elektowi sakry biskupiej $^{46}$. Konsekrację biskupią rozpoczynał gest włożenia na elekta rąk. Dokonywali tego wszyscy biorący udział $\mathrm{w}$ elekcji biskupi, modląc się w sercu o udzielenie wybranemu Ducha Swiętego. W tym czasie wszyscy pozostali, duchowieństwo i lud, przyjmując postawę stojącą również w ciszy błagali Boga o wylanie Ducha Swiętego na konsekrowanego.

Należy w tym miejscu podkreślić, że owo włożenie rąk należało do istotnego momentu święceń biskupich i oznaczało przekazanie wybranemu władzy apostołów. Na oznaczenie tego najważniejszego momentu przekazania sakry biskupiej używa się niekiedy od poł. III wieku wyrażenia: włożenie rąk. Tak np. św. Cyprian informuje, ze Sabinowi w miejsce Bazylidesa za zgodą ludu i biskupów zostały włożone ręce ${ }^{47}$. Natomiast wyznawcy rzymscy wracający ze schizmy przyznają, że zgodzili się, aby na Nowacjana ręce zostały włożone w taki sposób, jak to się dzieje przy wyświęceniu biskupa ${ }^{48}$.

Gdy dokonane zostało włożenie rąk, wydelegowany spośród zgromadzonego episkopatu biskup główny konsekrator kładł na nowo wybranym rękę, odmawiając następującą modlitwę konsekracyjną:

„Boże i Ojcze Pana naszego Jezusa Chrystusa, Ojcze miłosierdzia i Boże wszelkiej
pociechy, który przebywasz na wysokościach i spoglądasz na niskości, który znałeś
wszystko zanim powstało, Ty dałeś Kościołowi swemu przez Słowo Swojej laski,
przeznaczając od początku ród sprawiedliwych od Abrahama, umacniając książąt
i kaplanów i nie zostawiłeśs swojej świątyni bez opieki. Ty od początku wieków
zamierzyłeś w swojej dobroci objawić siebie w tych, których wybrałeś, przeto wylej
teraz z mocy Twojej, z Ducha Twego ochoczego, którego dałeś Swemu umilowa-
nemu Synowi Jezusowi Chrystusowi, którego On darował świętym Apostołom,
założycielom Kościoła, na każdym miejscu sławiącego Ciebie chwałą bez końca

${ }^{45}$ Por. Didascalia Apostolorum III 5; zob. J. Gaudemet, Les elections dans l'Église latine des origines au XVI siècle, Paris 1979, 20: „Lorsque tous ont donné témoignage, selon la vérité et non selon une opinion préconçue, qu'il presente bien ces qualités, comme devant le tribunal de Dieu et du Christ, en présence de Saint-Esprit, de tous les saints et de ceaux qui remplissent des fonctions sacres, pour la troisième fois, ils s'enquiérent de savoir s'il est veraiment digne du ministère".

46 Por. Didascalia VIII 4; zob. także W. Schenk, Laikat $w$ dziejach Kościola, ZN KUL 14 (1968), z. 1, 12.

47 Por. Cyprianus, Epistula 68, 5.

48 Por. tenże, Epistula 49, 1. 
i wysławiającego Twoje Imię. Ojcze, znający serca, daruj temu studze Twemu, wybranemu przez Ciebie na biskupa, aby pasł święte Twoje stado i nienagannie zachowywal przed Tobą pierwszeństwo kapłaństwa służeniem [Tobie] dniem i nocą, nieustannie jednając Twoje Oblicze i ofiarując dary Twego świętego Kościoła. I laskę Ducha, który upodobał sobie pierwszeństwo w kapłaństwie, aby miał władzę odpuszczania grzechów według Twego nakazu, a także rozwiązywania wszelkich więzów według władzy, jaką dałeś A postołom i dogadzał Tobie w lagodności i czystości serca, przynosząc Tobie wonności [modlitwy] przez Syna Twego Jezusa Chrystusa, przez którego przynależy Tobie chwała, potęga i cześć, Ojcu i Synowi ze Świętym Duchem, i teraz i na wieki wieków. Amen ${ }^{49}$.

Po tej modlitwie nowo wyświęcony biskup był pozdrawiany przez wszystkich pocałunkiem pokoju, następnie przystępował do przewodniczenia Liturgii Eucharystycznej, której słowa autor Tradycji Apostolskiej dokładnie przy tej okazji przytacza ${ }^{50}$.

Zrozumiałą jest rzeczą, że w elekcji nowego biskupa nie mogli uczestniczyć wszyscy biskupi danej prowincji kościelnej. Dlatego też ci biskupi, którzy brali udział w wyborze i konsekracji elekta, listownie powiadamiali pozostałych biskupów o obsadzeniu wakującej stolicy ${ }^{51}$. Czynił to także i nowo wyświęcony biskup śląc listy przynajmniej do główniejszych stolic biskupich prowincji ${ }^{52}$.

Mówiąc o wyborze biskupa Rzymu do IV wieku, warto jeszcze zauważyć pewne rozstrzygnięcie, jakie się w tym względzie pojawiło się gdzieś około 336 roku. Zasiadający w tym czasie na stolicy św. Piotra papież Marek, wydał dekret, w którym przywilej głównego konsekratora biskupa Rzymu przyznawał biskupom Ostii ${ }^{53}$. Była to $w$ jakimś sensie próba zabezpieczenia przed sytuacjami podobnymi do tej, jaka miała miejsce w połowie III wieku. Wtedy to rzymski kapłan Nowacjan, sprowadził do miasta trzech biskupów z maleńkich miejscowości Italii, nie bardzo rozeznanych w wewnętrznej sytuacji Kościoła Rzymskiego i zdołał nakłonić ich do udzielenia mu święceń ${ }^{54}$. Niedaleka przyszłość, związana ze sprawą cesarskiego kandydata, antypapieża Feliksa II (355-365), czy później kontrkandydata papieża Damazego, antypapieża Ursyna (366-367), miała pokazać wielkie znaczenie, wydanego przez papieża Marka rozporządzenia.

${ }^{49}$ Hippolytus, Traditio Apostolica 1, 3, SCh 11 bis, 42-46, thum. H. Paprocki, STV 14 (1976) z. $1,151$.

50 Por. tamże 1, 4, SCh 11 bis, 46-52.

51 Por. Cyprianus, Epistula 67, 5.

52 Por. tamże.

53 Por. Liber Pontificalis 35, 2, ed. L. Duchesne, Paris 1957-1958, s. 203.

54 Por. Eusebius, HE VI 43 (8). 
Zaprezentowany powyżej sposób przebiegu elekcji biskupów rzymskich, zdołał zwycięsko przeprowadzić papiestwo przez trudności wewnętrzne; jakie pojawiły się w chrześcijańskiej gminie rzymskiej przy wyborze takich papieży jak: Kalikst i Korneliusz w III wieku, czy Damazy w wieku IV. Zdołał się on także oprzeć zewnętrznym trudnościom, jakie najpierw przyniosło ze sobą wzniecone przez cesarza Dioklecjana prześladowanie, którego bolesnym skutkiem była kilkuletnia sediswakancja na stolicy biskupiej w Rzymie po śmierci papieża Marcellinusa († 305), a później cezaropapistycznym zapędom cesarza Konstancjusza, które w latach pięćdziesiątych IV stulecia doprowadziły do odsunięcia na jakiś czas od władzy papieża Liberiusza i osadzenia cesarskiego kandydata na stolicy biskupiej w Rzymie Feliksa II.

Przeprowadzona analiza zagadnienia wyboru biskupa Rzymu do IV wieku przybliżyła nam okres tworzenia się i funkcjonowania w tradycji szczegółowych rozstrzygnięć, co do sposobu elekcji biskupów rzymskich, który przygotował niezbędny grunt dla odpowiednich uchwał synodalnych, popartych autorytetem cesarskich rozporządzeń, których przykłady znajdujemy już w $\mathrm{V}$ wieku ${ }^{55}$. Stanowi ona też ważny przyczynek do szerszego spojrzenia na wybór biskupa Rzymu, który nie przestaje wciąż - jak to stwierdza Jan Paweł II w Konstytucji apostolskiej Universi Dominici gregis - przedmiotem szczególnej uwagi i troski w Kościele ${ }^{56}$.

\section{DIE WAHL DES BISCHOFS VON ROM BIS ZUM IV. JAHRHUNDERT}

\section{(Zusammenfassung)}

Die Wahl des Bischofs von Rom immer wieder ein Ereignis ist, dem die Kirche besonders viel Achtung und Sorge widmet. Zu diesem Thema haben sich alle Päpste XX (zwanzig) Jahrhunderts in entsprechenden Dokumenten geäußert. Auch Johann Paul II hat sich mit dieser Frage in einer getrennten Apostelkonstitution beschäftigt; ihr lateinischer Titel ist: Universi Dominici gregis. Im Punkt 84. dieses Dokuments stellt der Papst fest: , [...] Die Wahl des Hauptes der Kirche ist heutzutage in gewissem Sinne als eine Handlung der ganzen Kirche zu kennzeichnen". Wenn es tatsächlich so ist, erscheint uns die Thematik, die mit der Wahl der Nachfolger des Heiligen Petrus verbunden ist, sehr aktuell und bedarf einer eingehenden

55 Por. J. Gaudemet, art. cyt., s. 21n.

56 Por. Jan Paweł II, Universi Dominici gregis. Konstytucja Apostolska z 22 lutego 1996 roku, AAS 88 (1996) 305-343. 
Interpretation. Diese Thematik ist übrigens sowieso sehr interessant und wird jeweils bei der Wahl eines neuen Papstes immer wieder heftig diskutiert.

Apostel Peter hat als der einzige Mensch die Wunderwahl selber erfahren. Es kam aber ein Zeitpunkt, an dem sein Posten von einem anderen Menschen übernommen werden mußte. Es gab damals keine fertigen Vorschriften, die die Wahl seiner Nachfolger geregelt hätten. Im dieser Artikel können wir beobachten, wie diese Vorschriften erst langsam entstanden sind. Wir entdecken ihre Quellen in der Heiligen Schrift, in der jungen Tradition der Kirche sowie auch in den Rechtsgewohnheiten der Römer. 